International Journal of Social Sciences and Humanities
Available online at http://sciencescholar.us/journal/index.php/ijssh
Vol. 2 No. 3, December 2018, pages: 149 155
e-ISSN: 2550-7001, p-ISSN: 2550-701X
https://doi.org/10.29332/ijssh.v2n3.225

\title{
The Stylistics of Text: Wasiat Renungan Masa Pengalaman Baru
}

CrossMark

\section{Bohri Rahman ${ }^{a}$}

Article history: Received 8 April 2018, Accepted: 30 August 2018, Published: 23 November 2018

\section{Correspondence Author ${ }^{a}$}

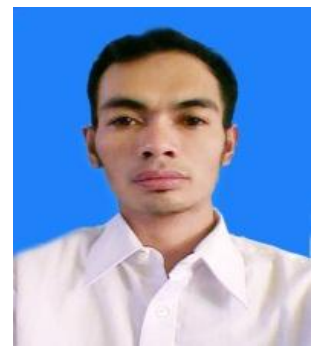

\section{Keywords}

cohesion of

foregrounding;

foregrounding;

language element;

stylistic;

wasiat renungan masa

pengalaman baru;

\section{Abstract}

The stylistic study towards wasiat renungan masa pengalaman baru text by Muhammad Zainuddin Abdul Majid was motivated by the fact that so far the interpretation of the text is not intact, namely only text interpreting to cohesion meaning. The interpretation of literary works must look at the meaning that arises due to foregrounding and cohesion of foregrounding. Stylistic studies in literature see how the language elements were used to revealing messages in literary works. Exploration, explanation, and interpretation of this text were important and strategic, due to the text was guided by hundreds of thousands of their follower who were members of Nahdlatul Wathan Organization. The stylistic study on Leech approach to the text suggests that the meanings contained in each stanza in the text not only contain cohesion but also contain many foregrounding, and cohesion of foregrounding meanings.

e-ISSN: 2550-7001, p-ISSN: 2550-701X ๑ Copyright 2018. The Author. SS Journals Published by Universidad Técnica de Manabí. This is an open-access article under the CC BY-SA 4.0 license (https://creativecommons.org/licenses/by-sa/4.0/) All rights reserved.

\section{Contents}

Abstract

1. Introduction

2. Materials and Methods

3. Results and Discussions

4. Conclusion

Acknowledgements..

a Universitas Qamarul Huda Badaruddin Bagu, Central Lombok, Indonesia 


\section{Introduction}

Wasiat renungan masa pengalaman baru is the verses of Muhammad Zainuddin Abdul Majid poem. He is a phenomenal figure for Lombok people in West Nusa Tenggara (NTB), even nationally. He was not only known for his involvement in the national political stage but also known to the public due to his great works. No wonder, in 2017, he was given the title of National Hero by Indonesian President Joko Widodo. In addition, he is also known from his istiqomah (perform worship and obedience to God continuously without interruption/doing all things with sincere and honest intentions) giving teachings about Islam science, establishing mosques, and establishing school, therefore, he was dubbed Abul Madaris wal Masajid which means the father of mosque and the father of school.

Abdul \& Adawiyah (2009), Ahmad (2016), one of his masterpieces is wasiat renungan masa pengalaman baru text. It is a message delivered to the teacher, father, leader, and founder of Nahdlatul Wathan Organization to their children, students, lovers, and society in general. It was first pronounced on the $23^{\text {rd }}$ of Ramadan $1376 \mathrm{H} / \mathrm{March} 23^{\text {rd }}$, $1957 \mathrm{AD}$, but in the new manuscript form was published in $1981 \mathrm{AD}$.

Barat, Gunawan \& Johari (2018), it will be divided into three groups of titles, namely (1) Wasiat renungan masa part I, is mentioned as wasiat renungan masa pengalaman baru. This section consists of 233 stanzas. (2) father wasiat (message) to his beloved son, this passage consists of 110 stanzas, and (3) The essential supplementary of wasiat renungan masa, this part consists of 88 stanzas. The three groups of titles have different physical characteristics, in part I of the array in each of the stanzas is four lines per second in part II and III each stanzas consisting of five lines. Each verse in this part II is added with the phrase "aduh sayang!" ("oh dear!"). In addition to adding addictive phrases, in part II also added "!" exclamation mark is on every expression of love. The phrase "aduh sayang" is repeated over 110 stanzas.

Majid \& Zainuddin (2002), this text has caused a changes variety or interpretations by the reader. Moreover, the author himself never explained the intent and meaning of the temple verse in the text. He seemed to let the readers of his text test themselves to what he conveyed in the poem form. Therefore, Nahdlatul Wathan $(N W)$ adherents (as the students are called) who are students and love him, has many interpretations of the text contents.

Widdowson et al., (1978/2014), diverse interpretations of the contents (meanings) for the future devotional testaments have led to a diversity of understandings among worshipers. Often differences in meaning understanding of testaments lead to division and conflict. Based on this issue, the author assumes that a specific and in-depth study of the text of the testamentary contemplation of the new experience is very important and urgent to conduct, moreover stylistic aspects studies.

\section{Materials and Methods}

This research is a literature discourse research. Thus, the research paradigm is humanities research. The shade under the humanities paradigm views qualitative research as the most relevant type of research. By adopting qualitative research characteristics, this research devoted all the potential to achieve a complete understanding of the meaning (fact) of the object or phenomenon under study.

\section{Theory}

The stylistic research on wasiat renungan masa pengalaman baru text used Leech (2014), stylistic theory as the synthesis point. Leech (2014), connected his linguistic description with critical interpretation. He revealed that literary works contain additional dimensions of meaning operating also in other discourses. For this reason, linguistic descriptions cannot be applied at all differently from other types of text. It was revealed three symptoms of literary expression that present different dimensions of meaning that are not covered by linguistic descriptions with normal categories. The three expression symptoms are cohesion, foregrounding, and cohesion of foregrounding.

Burhan (2002), Pradopo (1993), cohesion is an intertextuality relationship between the grammatical and lexical elements are interwoven into a text so that it becomes a complete discourse unit; thus, both convey the meaning of the text as a single entity. For example in the poem "This Bread I Break" there is lexical cohesion in the repetition of oat and break words and the relationship between lexical details together form semantic characteristics such as bread-oat-crops, and day-night-summer-sun. Leech (2014), also revealed cohesion is not unique in poetry but also in all other textual material because it is this cohesion combines linguistic units separately into meaningful discourse networks. 
In contrast to cohesion, Sudjiman (1993), Wellek \& Warren (1989), foregrounding is a typical symptom found only in literature. Foregrounding is a deliberate deviation from normal language norms. For example, Thomas uses expressions like 'the oat was merry'. In this sentence, the oat (non-living things) is characterized by human life. This expression deviates from normal expressions like 'the man was merry', and 'the farmer was merry'. Then, it also found deviations from the normal selection of Thomas's poetry. The phrases 'broke the...' usually associated with fragile objects like 'cup', 'plate', and 'clock'. But in the poem the phrase 'broke the...' is mated with noun 'sun' so that there is a deviation. Leech (2014), argued that foregrounding occurred when semantic features of language element used are not related to the semantic characteristics given to them by the contextual environment in which the element appears.

Short \& Leech (2013), also stated other manifestations of foregrounding symptoms. This happens if the writer instead uses a lot of choices but prefers to use a uniform form that actually creates diversity. For example, forming a sentence that is equivalent to two prepositional phrases. The same sentence parallelism occurs at the end of the poem line, 'my wine you drink, my bread you snap'.

The cohesion of foregrounding is deviations in the text are connected with other forms to intratextual patterns form. For example, the expression 'brake the sun' deviates from normal language but becomes normal in the context of the poem as a whole, because this deviation is related to deviations which are the same as 'broke the grape's joy', and 'pulled the wind down'. Reaske (1966), Subroto (1976), intratextual patterns are also formed by the cohesiveness of deviant expressions such as 'the oat was merry' and 'sensual root'.

\section{Results and Discussions}

The text meaning of wasiat renungan masa pengalaman baru is stopped at the lexical meaning and grammatical meaning. As a result, the meaning generated by connotative meanings is not correctly interpreted. Next, it is the text exposure "Father messages to his beloved child"

14. Aduh sayang!

Konon ada menjual gurunya Menjual Ibu serta Bapaknya Menjual NW dan Madrasahnya Na'uzubillah apa jadinya ....

15. Aduh sayang! Organisaasi ada IMAMNYA

Pengurus Besar $(P B)$ namanya Wajib dito'ati Instruksinya

Selama berjalan menyelamatkannya

17. Aduh sayang!

Kalau Imam mulai takbirnya

Harus Ma'mum mulai pula

Bila Imam salamnya nyata

Haruslah Ma'mum salam merata

18. Aduh sayang!

Kalau anakku masih mengaku

Bahwa NW Organisasimu

Pastilah 'nakku Tho'at seribu

Menurut "IMAM" kompak selalu
14. Oh dear!

It is said that there are selling teachers

Selling his mother and father

Selling NW and its school

What is the Na'uzubillah ...

15. Oh dear!

The organization has blushing General Manager (GM) name It is obligatory in the Instructions

During his walk saved him

17. Oh dear!

If the blushing starts Almighty God

Must be Ma'mum too

When the Imam's greeting is real

Must be Ma'mum greeting evenly

18. Oh dear!

If my child still confesses

That NW of your organization

Surely 'my son Tho' at one thousand

According to "IMAM" it is always

compact

The text quoted above is a quote from the $14^{\text {th }}$ and $15^{\text {th }}$ verses, $17^{\text {th }}$, and $18^{\text {th }}$ verses. This section is the second part which is 112 stanzas. The second part is given the title "Wasiat (mandate) of the father to his beloved children". The first stanza to the hundredth stanza in this section always starts with the phrase "aduh sayang" on the first array, then followed by the second array to the fifth array.

Beginning the taxation with the phrase "aduh sayang" and occurred continuously until the $112^{\text {th }}$ stanza, is a unique feature of this text. The addition of the phrase makes each strophe not consist of four arrays, but becomes five

Rahman, B. (2018). The stylistics of text: wasiat renungan masa pengalaman baru. International Journal of Social Sciences and Humanities, 2(3), 149-155. https://doi.org/10.29332/ijssh.v2n3.225 
lines. If we look at poetry forms that are contemporary with the text written, we will find a breakthrough in poetry writing, because in those days the poetry writing was still very much bound by the standard rules of poetry writing.

Returning to the first-row repetition "aduh sayang" repeatedly 112 times, shows how parents should advise their child. This text goes to the reader to advise the youth to be gentle, with the language that touches his heart. In such a way, advice will be acceptable to young people. In the $18^{\text {th }}$ verse it is stated: //Aduh sayang//, //Kalau anakku masih mengaku//, //Bahwa NW Organisasimu//, //Pastilah anakku Tho'at seribu//, //Menurut "IMAM" kompak selalu//. The arithmetic of this stanza has a very clear grammatical and lexical cohesion. The meaning of it lines is firmly understood as the conventional meaning attached to it. That claims to be part of NW organization, must obey the Organization leader.

Foregrounding in the $18^{\text {th }}$ verse occurs emphasis of its meaning. Actually, this stanza is hard and firm. The goal is clear and swooping at the problem. If someone claims to be part of NW organization, s/he must obey what has been outlined by the leader. But the use of figurative language and analogy makes the doctrine feel soft. The use of the word "jika" ("if"), "umpama"/"for example", "misalnya"/" example", "andai kata"/"instance", and "seandainya"/"supposing", in the second verse is intended as a presupposition, but does not mean to presuppose something that is still empty or blurred rather the strong emphasis is that "jika ini maka inilah yang harus"/"if this is what this should be". But the author uses "kalau"" "if" to further alleviate the psychological burden of the array without having to reduce the level of meaning to be emphasized by the array.

The word "kalau"/"if" consciously or not actually has higher potential than words that are in its environment included "jika" ("if"), "umpama"/"for example", "misalnya"/" example", and others. In addition, "kalau"/"if" has a rhyme that connects with the next word in the array which also ends with $u$, namely anakku/my child, dan mengaku/confesses. Of course, this kind of acceptance is important in a poem to create melodies and emphasize the aesthetic meaning of poetry in a poem.

The word choice "kalau"/"if" is then followed by "anakku"/"my child", Psychologically, an advisor will create emotional closeness with the person s/he wants to diagnose. The use of the term my child clearly intends to bring the writer of the text closer as the message with the text read as the recipient of the message. By creating this emotional closeness, it is expected that the reader as the recipient of the message can be more easily touched by his/her emotions to receive all the contents of what is inherited. Creating this kind of emotional closeness is important because, in addition to alleviating the psychological burden without reducing the pressure of his/her doctrine, it also creates a mystical atmosphere and creates deep comfort for the reader as the doctrine recipient.

The doctrine that the verse wants to aim for is actually clear in the $4^{\text {th }}$ and $5^{\text {th }}$ array. In the $4^{\text {th }}$ and $5^{\text {th }}$ array, it is stated: //Pastilah anakku Tho'at seribu//, //Menurut "IMAM" kompak selalu//. Tho'at uses Arabic pronunciation dialects gets very strong pressing with the next word "seribu"/"thousand". Obedience is desired not only obedient, but the obedience that is desired is truly obedient, obedient to approaching piety. Obedience inwardly. Why is that, the obedience that is only obedient will make his sympathizers and NW Organization founded only obey when benefiting only the sympathizers, even though what this text wants is militant sympathizers, sympathizers who sincerely born out follow what direction and instructions organizational leaders. Investigators who are willing to defend the organization even with sweat, blood, and even life "Tho'at seribu".

To whom the sympathizers must obey, it has also been stated by the next array to "IMAM". The term used in this array was intended to analogize the leaders of NW organization. Organizational leaders are represented by the general manager. The sympathizers must obey what the GM has outlined because the big management is imam in the organization. In the $15^{\text {th }}$ verse, it says "Aduh sayang! // Organisaasi ada IMAMNYA // Pengurus Besar (PB) namanya // Wajib dito'ati Instruksinya // selama berjalan menyelamatkannya".

The obedience doctrine is to the struggle of NW organization does not stop at only the $18^{\text {th }}$ verse and $15^{\text {th }}$ verse. In the $14^{\text {th }}$ verse stated //Aduh sayang!//, //Konon ada menjual gurunya//, //menjual Ibu serta Bapaknya//, //Menjual $N W$ dan Madrasahnya//, I/Na'utubillah apa jadinya//. The cohesion of foregrounding in this verse feels stronger. If in the $18^{\text {th }}$ verse, the doctrine is refined by using the words choice have soft character but have existence, quality and capabilities are strong in manifesting intended doctrinal meaning, not so with this $14^{\text {th }}$ verse. The $14^{\text {th }}$ verse of the text was wrapped by a strong figurative language. The word selling his/her teacher in the sociocultural understanding of Indonesian has a negative and unusual connotation meaning. Teachers in Indonesian culture, in general, are someone who must be respected, nurtured and imitated because of his/her wisdom in looking at and living life. The term menjual guru/selling teacher experiences a deviation of meaning referred to Leech (2014), with chosion of foregrounding. The teacher is likened to a merchandise can be bought and sold. This metaphor intends to refine but at the same time place on the cynicism and ironism that is alarming. 
On the third array is stated //menjual Ibu serta Bapaknya//. This array further reinforces the parable while emphasizing the ironic dimension of the subject in question. He wants to emphasize that there will be at the future time people who have the heart to sell themselves and sell NW. Selling the father/mother was meant NW organization he founded. The $14^{\text {th }}$ verse ends with an Arabic expression that shows he regrets. The situation reveals with //Na'uzubillah apa jadinya// expression shows us that the author of the message text is very sorry and hopes that this situation should not occur. But in fact, after almost a hundred years of the message was written, such an event really happened, where the politicians sold his/her figure and sold the organization he founded as a place of the political victory.

The word choice "konon"/"purported" is then followed by "ada yang menjual gurunya"/" someone who sells his teacher". Guru/teacher is placed ahead of "selling his mother". This shows that he wants to intimidate the mass that the teacher occupies a place more than the parents. This is also in accordance with the teachings of the Islamic religion order must be obeyed is Almighty God, then Muhammad Rasulullah, only after that the Teacher shows and teaches kindness and filial ways, then it is obligatory to worship parents who have given birth.

\section{Conclusion}

Discussing stylist about the above text will not reach the saturation point, especially the study using Leech (2014), approach. In addition to the choice of text words that have a very complex sentence structure and semantic system, the linguistic deviation proposed by Leech (2014), is also really applied in the text. As a result, readers and followers of the text cannot understand the text message in foregrounding meaning. For example, when the text talks about regeneration, this text is very pronounced and its effectiveness is also proven. In fact, the text meaning is often misused by those who just ride the NW and NW period to get a position. Of course, the reason is for the NW struggle. Unlike people often interpret this text according to their own interests without the need to think more deeply and more wisely to interpret the text. Even though, the word for word in the text contains a number of meaningless sheets that have not been revealed.

\section{Acknowledgments}

This research was conducted and funding by Universitas Qamarul Huda Badaruddin Bagu, Central Lombok. The author thanks the Rector of Universitas Qamarul Huda Badaruddin Bagu, Chairman of LPPM Universitas Qamarul Huda Badaruddin Bagu, and all Uniqhba Bagu academics who have contributed to the present research.

Rahman, B. (2018). The stylistics of text: wasiat renungan masa pengalaman baru. International Journal of Social Sciences and Humanities, 2(3), 149-155. https://doi.org/10.29332/ijssh.v2n3.225 


\section{References}

Abdul, T. G. K. S. Z. Madjid. Wasiat Renungan Masa: Pengalaman Baru.

Adawiyah, M. (2009). Pendidikan Pesantren Menurut Pemikiran Tuan Guru Kiai Haji Muhammad Zainuddin Abdul Majid.

Ahmad, M. (2016). gagasan nilai-nilai pendidikan karakter tgkh. m. zainudin abdul madjid dalam wasiat renungan masa pengalaman baru. El-Hikam, 8(2), 233-266.

Barat, A. A. G. L. gagasan nilai-nilai pendidikan karakter TGKH. M. Zainudin abdul madjid dalam wasiat renungan masa pengalaman baru.

Burhan, N. (2002). Teori Pengkajian Fiksi.

Gunawan, H. representasi kearifan lokal suku sasak dalam wasiat renungan masa pengalaman baru karya tuan guru kyai haji muhammad zainuddin abdul majid.

Johari, T. (2018). transitivity in wasiat renungan masa pengalaman baru and its relevance to indonesian language learning at senior high school: SFL approach. International Journal of Systemic Functional Linguistics, 1(2), 4752.

Leech, G. (2014). Language in literature: Style and foregrounding. Routledge.

Leech, G. N. (2014). A linguistic guide to English poetry. Routledge.

Madjid, M. Z. A. nilai pendidikan karakter dalam wasiat renungan masa tuan guru kyai haji.

Majid, A., \& Zainuddin, T. G. H. M. (2002). Wasiat Renungan Masa Pengalaman Baru.

Majid, M. Z. A. konsep pendidikan akhlak dalam buku wasiat renungan masa tuan guru kyai haji.

Pradopo, R. D. (1993). Stilistika (Artikel).

Reaske, C. R. (1966). How to analyze poetry. Arco.

Short, M. H., \& Leech, G. N. (2013). Style in fiction: A linguistic introduction to English fictional prose. Routledge.

Subroto, D. E. (1976). Hakekat Bahasa dan Realisasinya dalam Puisi.” dalam Majalah Bahasa dan Sastra.

Sudjiman, P. H. M. (1993). Bunga rampai stilistika. Pustaka Utama Grafiti.

Wellek, R., \& Warren, A. (1989). Teori Kesusasteraan (terjemahan dari Theory of Literature oleh Melani Budianta). Jakarta: Gramedia.

Widdowson, H. G. (2014). Stylistics and the Teaching of Literature. Routledge.

Widdowson, H. G. dalam Allen, JPH dan Corder, SP.(Ed.).(1978). "Stylistics". 


\section{Biography of Author}

\begin{tabular}{|l|l|}
\hline Bohri Rahman was born in Repok Ngampong, Central Lombok, December 31 & st, 1983. \\
He is a lecturer at Indonesian Language and Literature Education Studies Program, \\
FKIP Universitas Qamarul Huda Badaruddin Bagu. He currently is a doctoral student at \\
Linguistics Doctoral Studies Program, Faculty of Art, Universitas Udayana. \\
Email: boharirahman143@gmail.com
\end{tabular}

Rahman, B. (2018). The stylistics of text: wasiat renungan masa pengalaman baru. International Journal of Social Sciences and Humanities, 2(3), 149-155. https://doi.org/10.29332/ijssh.v2n3.225 